附梌

\title{
マグネシヤ耐火物の試驗研究 (II)
}

\author{
マグネシャ煉瓦の所謂消化作用に對するー試驗
}

\section{三田 正揚 - 西田 一雄 - 小畑 政男}

\section{I. 緒言}

マグネシヤ煉瓦は耐火度高く監基性にて, 愺が監基性なる精練法 にありては特に稳用せられ，然も原料の品質低下と共に 鹽基性精練 が大に行はれ來り, 之に件ひてマグネシヤ煉瓦の需要も飛躍的に霄 大しつ〉ある. 之と共に煉瓦の品質の向上も亦大に希望せらる〉處 である. マグネシヤ徚瓦の缺點の一と考へらる」は所謂消化と稳せ らる小性質にある。

消化とは水蒸氣によりて水酸化作用を受け崩壊するに到る事を云 ひ，マグネシヤ煉瓦の良否判定の最簡の方法は此の消化試驗にあり と迄論ぜられて居る向もある. その試驗方法はオートクレーブ中に 適當の大さの煉瓦を扣き，外部よりの加熱によりて該オートクレー ブ中に於て熱火蒸氣を發せしめ, その加槺水蒸氣によりて一定壓, 一定時間を保ちたる後煉瓦に 發生する龜裂の狀態を觀察決定するの が普通である. 此の方法は或は煉瓦が崩壞する迄の加筑加熱時間或


例によつて行つてるる. 此所に述ぶる試驗は此のオートクレーブ法 消化試驗に對する 數的判定を下し適確に比較し得られる樣な條件を 求める爲に實驗したものである.

1. 昭和製鋼所研究所

2. 永井博士は蒸壊等の語を提唱せらるつが，てつでは舊來の㭔稃 に從つた.

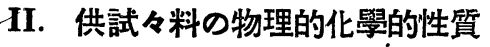

供試々料は當所竿業課にて製作せられたる並型徚瓦の試作品に加 ふるに市販のもの 1 種より特に燒縮り均一なるものを選んだ.

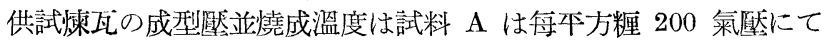
成型 SK 17 にて 12 時問保持燒成. 試料 B は每本方糎 300 氣厢 で成型 SK 20 にて 24 洔間保持䍃成. 試料 C \&市販品にて分幡製 鐵所弿業課河內課長より暌られたりのにてその製造條件は詳でな w.

\section{（1）試料の常溫耐壓强度}

試料の常溫に於ける耐厭强度を測つた結果を第 1 表に揭げる. 之 等の試料中 $\mathrm{A}$ 及 $\mathrm{B}$ は 20 數個のものより, $\mathrm{C}$ は 10 個の子のより 出來るだけ外觀より燒縮りの本均したものを探り且的厚强度も近似 したりのを採つたのであるがその中でも A 及 B は本均した試料で あつた. C には長高 $684.4 \mathrm{~kg} / \mathrm{cm}^{2}$ より最低 $109.4 \mathrm{~kg} / \mathrm{cm}^{2}$ にて A 及 Bに比し相當不揃であつたがこっには測定性の近似のもののみを以 て實驗を行つた。

\section{第 1 表 試驗煉瓦の耐埾强度表}

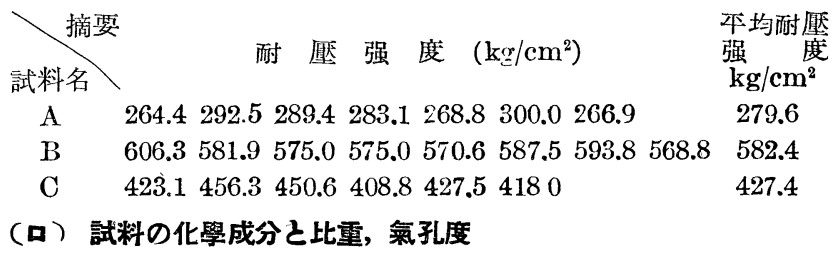

第 2 表に試驗煤瓦の化學成分及ゼーガー氏法によつて測定した嵩 比重, 氣孔度を揭げる.

$\mathrm{A}$ は $\mathrm{CaO}$ が他に比し多いが $\mathrm{Fe}_{2} \mathrm{O}_{3}$ す亦多い. $\mathrm{C}$ は $\mathrm{SiO}_{2}$ が多 い. 比重を比較すると B が一番重く, C 之に次ぎ A が一番輕い. 氣孔率は之に反する. 憢縮りの順を示して居る.

第 2 表 試驗煉瓦の化學成分並氣孔度，高比重表 (本均試料に依る)



\section{（ハ） 試料の熱間膨脹}

之等の試料の加熱による膨脹を檢したるに第 3 表及第 1 圖に示 す樣な結果を得た. $\mathrm{A}$ は $1400^{\circ} \mathrm{C} \sim 1450^{\circ} \mathrm{C}$ 間で收縮して居る. 之に よつても燒縮り不充分で燒成溫度が低い事が制る。

第 3 表 試驗煉瓦の膨脤率表

摘姴
溫度
常溫
100
200
300
400
500
600
700
800
900
1000
1100
1200
1250
1300
1350
1400
1450
1500

\begin{tabular}{|c|c|c|}
\hline A & $\mathrm{B}$ & $\mathrm{C}$ \\
\hline 0 & 0 & 0 \\
\hline 0.10 & 0.10 & 0.10 \\
\hline 0.22 & 0.22 & 0.20 \\
\hline 0.34 & 0.34 & 0.28 \\
\hline 0.46 & 0.48 & 0.38 \\
\hline 0.56 & 0.62 & 0.50 \\
\hline 0.66 & 0.76 & 0.64 \\
\hline 0.78 & 0.88 & 0.78 \\
\hline 0.92 & 1.00 & 0.92 \\
\hline 1.06 & 1.14 & 1.12 \\
\hline 1.22 & 1.30 & 1.36 \\
\hline 1.50 & 1.56 & 1.54 \\
\hline 1.70 & 1.82 & 170 \\
\hline 1.80 & 1.92 & 1.76 \\
\hline 1.88 & 2.00 & 1.82 \\
\hline 1.94 & 2.06 & 1.88 \\
\hline 1.98 & 2.10 & 1.94 \\
\hline 1.98 & 2.14 & 2.02 \\
\hline 1.86 & 2.18 & 2.08 \\
\hline
\end{tabular}


第 1 圖 膨脤率曲線圖



\section{III。實驗方法に就て}

\section{(の) 誠片の調慜}

第 2 圆

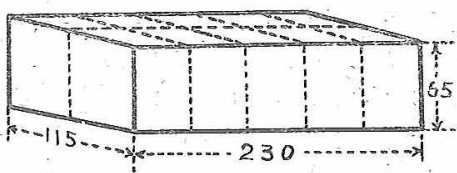

試险に際して应並型悚 瓦より第2 圖の如く，最 初 10 個の䓂片を多方ネ にて切り取り，之が四圍 をエメリーグラインダー で修擦し表面を仕上げて 大さ約 $40 \times 40 \times 60$ 䊈をる試片を作り周園の狀態を同一條件々せしめ る樣にしたるのでする。

(口) 測 定 方 法

消化試臉器は道常用るられるもので第 3 圖に示す装埴のオートタ




をなし䋨めつけ密閉し然る後器の下底より瓦斯绉を以て加熱し，40

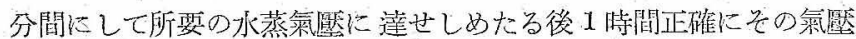
に保ち，炏に消火し1時間の後取出して其の變化の状態を檢査しそ の中のエ 個を取り直ちに耐筑强度を测定した。，その他は直ちに再び 舊の如く置き密閉加熱して再び所定蒸氣壓とし1時間の後聂出して その狀態を觀察し，その中の1個をとり㨁ちに耐畨强度を测定す

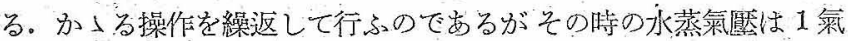

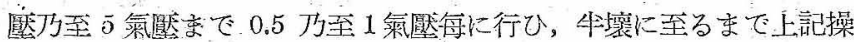

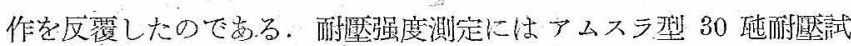

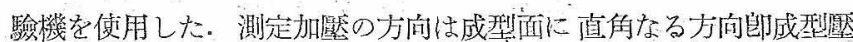


との三者の關係を考察したもので亦。
第 3 圖

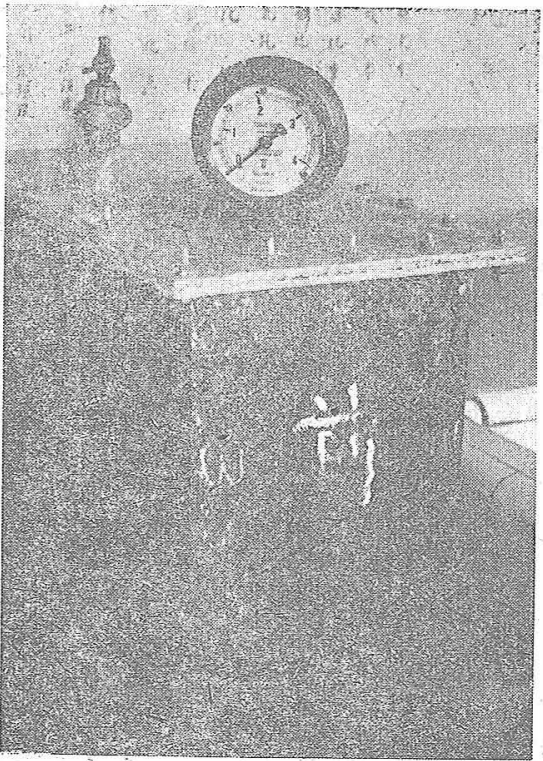

IV. 實驗結果及栲察

以上の樣な万法で行つた賔驗の結果は試料 A に對するものは第4

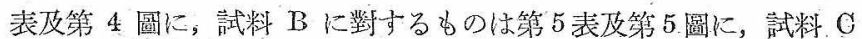
に對するるのは第 6 表皮第 6 圖に之を示してある。

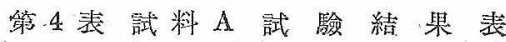
處理前附原强度 (A) $279.6 \mathrm{~kg} / \mathrm{cm}^{2}$






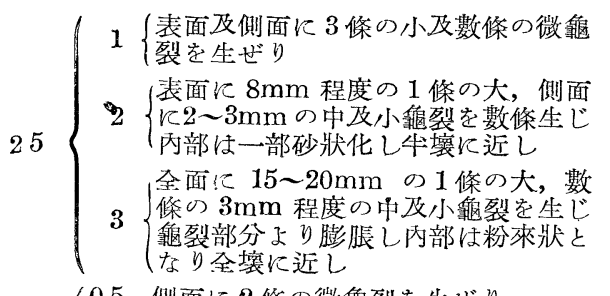

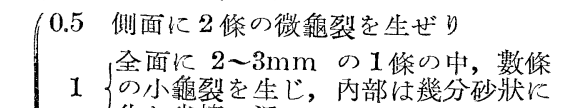
化し牛褱沉近し

3 龜裂部分壙大乙全面儿 $15 \mathrm{~mm}$ 程度

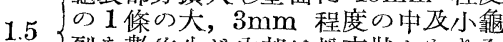
裂定數條生じ內部は粉末狀となり全 袈炕近乙

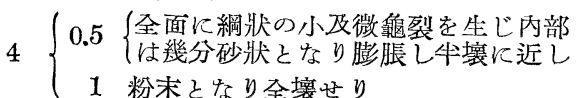

第 5 表試料 B 試 驗 結 果 表 處理前耐晾强度 (A) $582.4 \mathrm{~kg} / \mathrm{cm}^{2}$

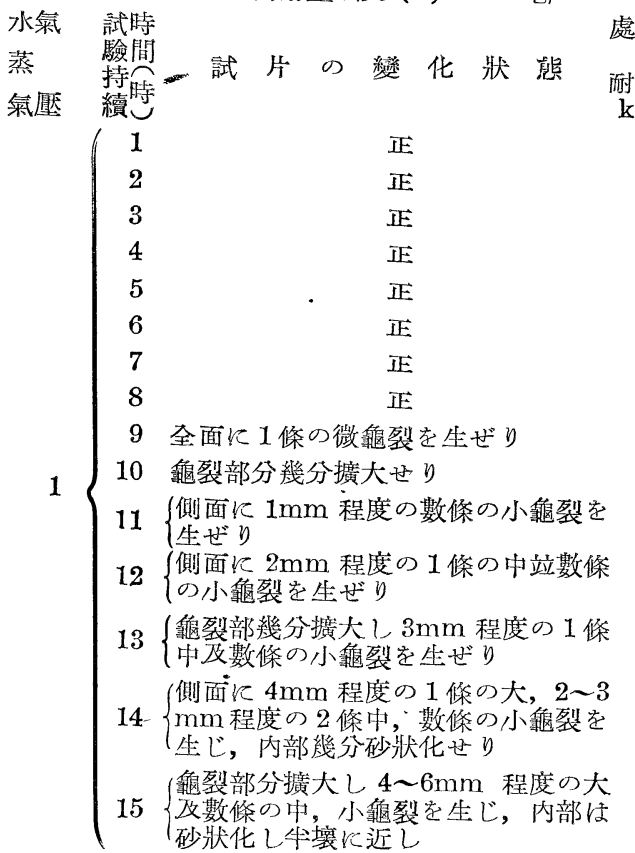

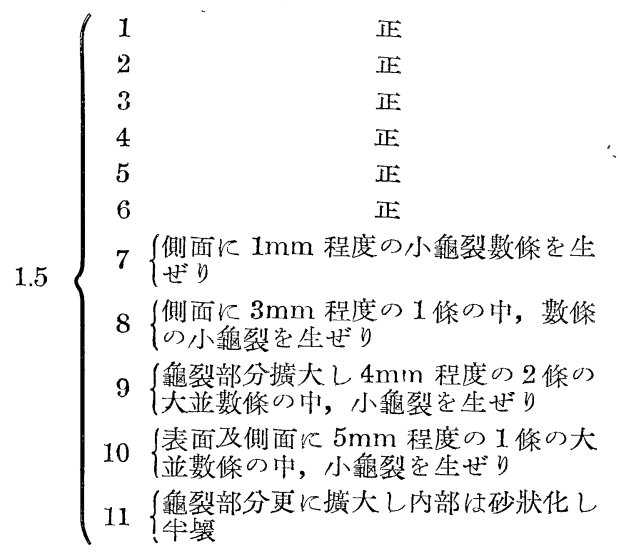

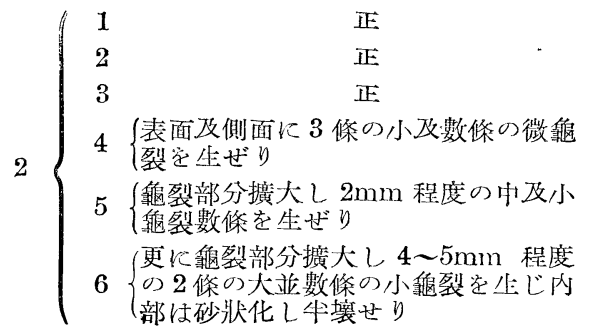

$\begin{array}{rr}86.3 & 30.9 \\ 20.6 & 7.4 \\ & \\ 2.5 & 0.9 \\ 95.0 & 34.0 \\ 12.5 & 4.5 \\ & \\ 1.2 & 0.4 \\ & \\ 14.4 & 5.2 \\ 0 & 0\end{array}$

\section{表} 處理後 $(\mathrm{B})^{-} \cdot \mathrm{B} / \mathrm{A}$ 厥强度 $\times 100$ $\mathrm{kg} / \mathrm{cm}^{2} \quad(\%)$ $562.5 \quad 99.6$ $534.4 \quad 91.6$ $508.8 \quad 87.4$ $476.3 \quad 81.8$ $435.6 \quad 74.8$ $396.9 \quad 68.1$ $351.9 \quad 60.4$ $313.6 \quad 53.8$ $275.0 \quad 47.2$ $233.6 \quad 40.1$

$190.0 \quad 32.6$

$135.6 \quad 23.3$

$73.8 \quad 12.7$

$46.3 \quad 7.9$

$\begin{array}{ll}3.8 & 0.7\end{array}$

$538.8 \quad 92.5$

$508.8 \quad 87.4$

$473.1 \quad 81.2$

$423.8 \quad 728$

$375.0 \quad 64.4$

$316.9 \quad 54.4$

$254.4 \quad 43.7$

$191.3 \quad 32.8$

$81.9 \quad 14.1$

$40.0 \quad 6.9$

$2.5 \quad 0.4$

$481.3 \quad 82.6$

$437.5 \quad 75.1$

$371.9 \quad 63.9$

$260.1 \quad 44.7$

$83.1 \quad 14.3$

$62 \quad 1.1$<smiles>CCCC</smiles>

正

409.4

326.9

3 表面及㑯面に 3 條の小龜裂を生ぜり 228.8 鼅裂部分擴大乙 $4 \mathrm{~mm}$ 程度の 1 條の

4 大並數條の中，小龜裂を生じ內部は 57.5 幾分砂狀化せり

全面飞 $10 \mathrm{~mm}$ 程度の1條の大並 2

$5\{$ 法m 程度の數條大中小龜裂业生 じ內部は砂狀化し全燷に近し

$\begin{array}{llll}0.5 & \text { 正 } & 3606 & 619\end{array}$

1 側面に 2 條の微龜裂を生ぜり $\quad 268.846 .2$



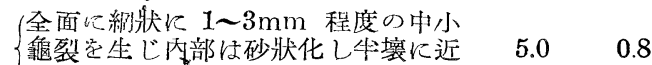
\{

2.5 砂狀となり全壞

$\begin{array}{llll}0.5 & \text { 正 } & 248.1 & 42.6\end{array}$

1 全面に數條の微挋裂を生ぜり $\quad 155.0 \quad 26.6$

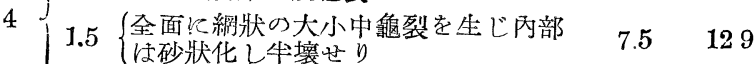

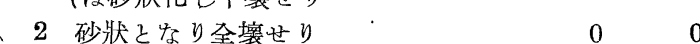

$5\left\{\begin{array}{llll}0.5 & \text { 全面に數條の小及微魄裂を生ぜり } & 164.4 & 28.2\end{array}\right.$

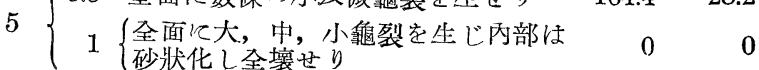

第 6 表 試料 $\mathrm{C}$ 試 驗 結 果 表 處理前の耐嫄强度 (A) $427.4 \mathrm{~kg} / \mathrm{cm}^{2}$



$\begin{array}{llll}1 & \text { 正 } & 371.9 & 87.0\end{array}$

正 293.8

68.7

3 表面並側面儿1條の小龜裂を生ぜり $205.0 \quad 48.0$

(表面並側面飞 1.5 2 $\mathrm{mm}$ 程度の 1

4 悠の中文 $0.5 \mathrm{~mm}$ 程度の 2 條の小龜 98.123 .0 裂を生ぜり

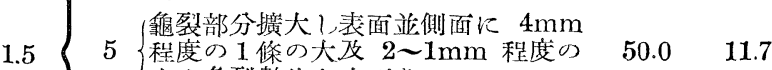
龜裂部分更に境大し側面に5 7 $\mathrm{mm}$

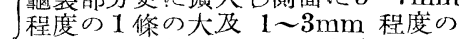

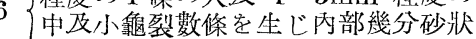
化地り

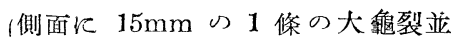

$7\{5 \mathrm{~mm}$ 程度の數條の中輡裂を生じ內 部砂狀化ぜ牛壇

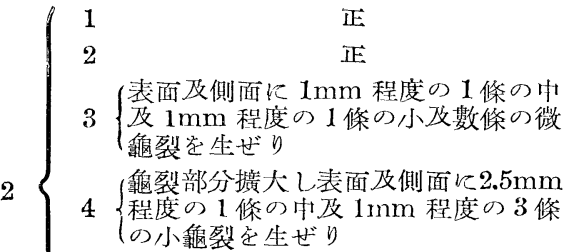

312.5 250.0

58.5

$129.4 \quad 30.3$

431

10.1 
㸡裂部分更に擴大し，表面側面に 5 $\sim 8 \mathrm{~mm}$ 程度の 2 條の大並 $2 \mathrm{~mm}$ 程

表面及側面に $10 \sim 15 \mathrm{~mm}$ 程度の 2

2.5

$4\{\sim 7 \mathrm{~mm}$ 程度の 2 條の大, $2 \sim 3 \mathrm{~mm}$

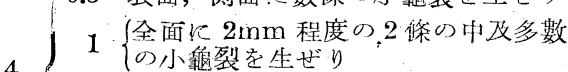

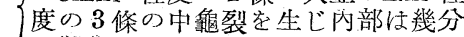
砂狀化せり

6 條の大及 $5 \mathrm{~mm}$ の1條の大,數條の中 小鼠裂を生じ，內部怯砂狀化し牛篦

1 表面及側面に2 條の微龜裂定生ぜり

2 表面及侧面に $1 \mathrm{~mm}$ 程度の 3 條の小 門裂を生ぜり

龜裂部分撗大し表面及側面儿 $3 \mathrm{~m}$ 学

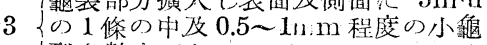
裂多數生ぜり

龜裂部分更儿擴大 ᄂ,表面及侧面に4 $\{$ 程度の數條の小粶裂を生じ内部は幾 分砂狀化女り

表面及側面に 8 - 15mm の2 條の大

5 文 $3 \mathrm{~mm}$ 程度の中鹅裂數條生じ, 內 部は砂狀化し全壤

1 全面に $1 \mathrm{~mm}$ 程度の小龜裂數條生ぜ

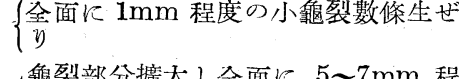

龜裂部分擴大し全面に 5 7 mm 程 $\left\{\begin{array}{l}\text { 度の } \\ \text { ぜり }\end{array}\right.$

表面，側面儿 8 $10 \mathrm{~mm}$ 程度の 3 條

$2\{$ の大及數條の中, 小龜裂を生じ, 內 部は砂狀となり全壊に近し

0.5 表面, 側面に數條の小龜裂定生ぜり $1.5\left\{\begin{array}{l}\text { 全面に } 4 \mathrm{~mm} \text { 程度の } 2 \text { 條の大並多數 } \\ \text { 中, 小裂学生じ內部は砂状化せ }\end{array}\right.$

19.1

4.5

$2.5 \quad 0.6$

$225.0 \quad 52.6$

$125.0 \quad 29.2$

$34.4 \quad 8.0$

10.9

2.6

162.5

38.8

9.1

11326

$0.6 \quad 0.1$

$77.5 \quad 18.1$

$15.6 \quad 3.6$

1.8

0.4

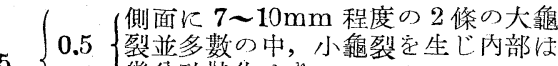

1 粉末狀態となり全壊せり

$0-0$ 幾分砂狀化せり

第 5 圖 マグネシャ徚瓦の消化試殮曲線

試 $\mu_{1} \mathrm{~B}$

水蒸氣氣壓，時間並彪減率との關係曲線

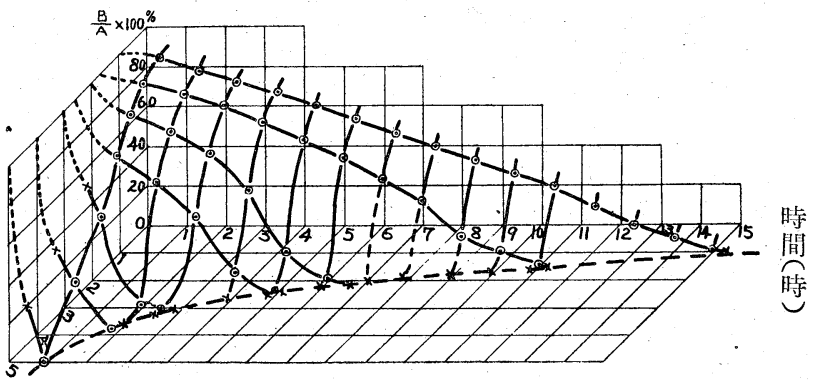

水蒸氣氣壓

第 6 圖 マグネシャ煉瓦の消化試驗曲線

試 $\begin{array}{lll}\pi^{\prime} & \mathrm{C}\end{array}$

表に於ては第 3 欄に肉眼に於て 觀察した狀態を耐厴試驗を計る每 に記述し，第 4 欄に測定而撮强度を記し，第 5 欄には原耐壓强度に

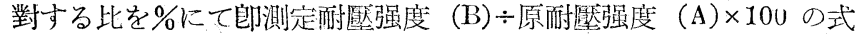

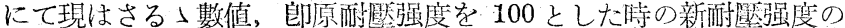
關係數值を\%で示してある. 圖に於ては此の第 5 欄を水蒸氣檿と時 間とに對結の表面の交線を揭げてある。肉眼觀察を更に明確にする 䳩に一例として寫且符 1 には試料 $A$, 寫眞第 2 には試料 $B$, 寫真第 3 には試料 $\mathrm{C} の 1$ 氣監に於ける狀態の變化を示してある.

第 4 圖 マグネシヤ煉瓦の消化試驗曲線

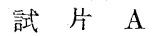

水蒸氣氣厴，時間並耐壓强度關係曲線

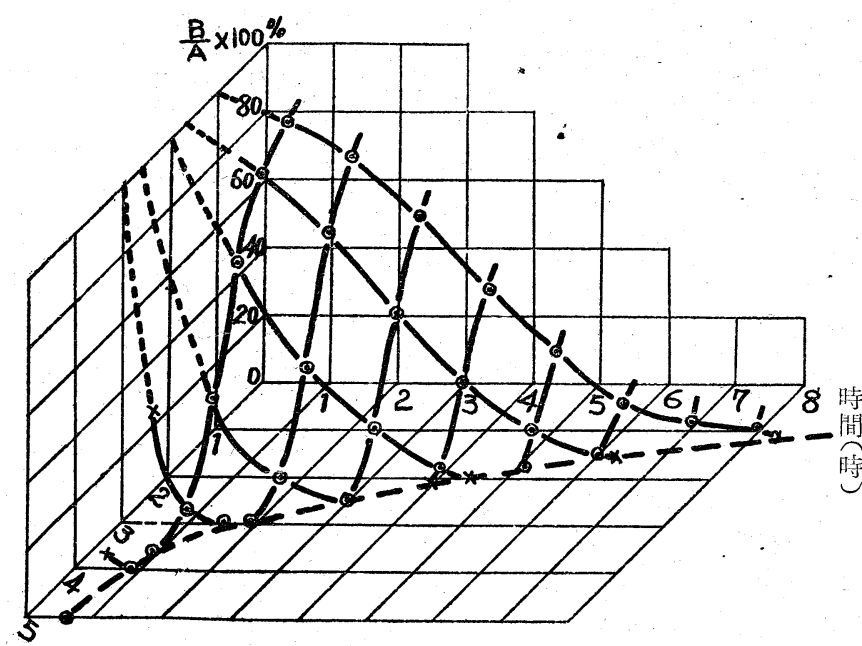

水蒸氣氣厴

\section{水蒸氣氣厴, 時間並耐壓强度關係曲線}

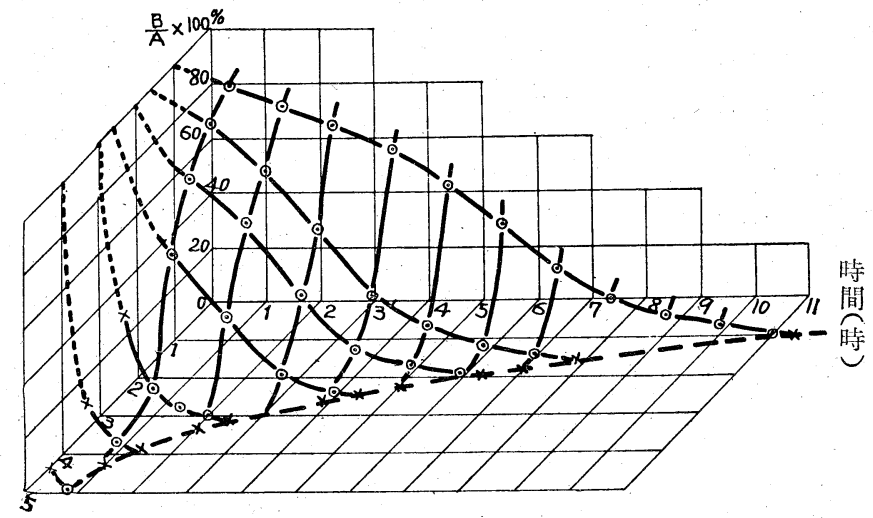

水蒸氣氣壓

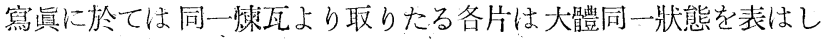
て居ることがわかる。

上記の各曲線より耐獎强度が丁度 $\mathrm{O}$ となる位㯰郎ち全崩壤の僢間 を求める.之が蒸氣壓の變化によりて變化する狀態は第 7 圖に示さ るっ曲線となる。○印は時間一定の曲線より,X印は氣㢡一定の曲線 より求めたる結果を示す. 此の曲線は抛物線的曲線をなすもので塟 縮り惡しきものは時間軸に近づき方が早く，憢縮り良きものは軸に 近づく時間が長く其軸に對し漸近線的になる。水分の吸着と共に

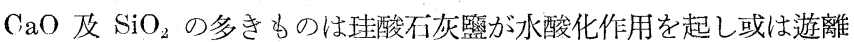
不灰が水酸化カルシウムとなる特に凝結力の減少を來し又同時に體 積の膨脤を生じ崩壊狀態を來すものと考へられて居る。比較的低き 溫度に拎ける $\mathrm{MgO}$ の水化作用についての不川呚授の研究結果によ れぼ $\mathrm{MgO}$ 女亦水化せられるもので, 最初 $\mathrm{MgO}$ の粒子間に水蒸氣 を吸着し然る後徐々に承化作用を及ぼすものと結論し居る。但し實 際にはクリンカーは簡單に消化し難いものである。

第 7 圖 マグ䊝シャ煉瓦の淮化試驗結果

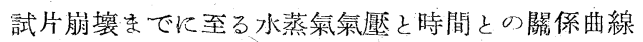

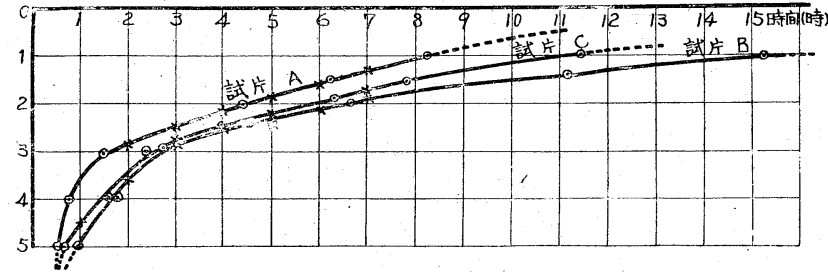

水蒸韱氣壓 
供試湅瓦に於て成型壓の低く燒縮りの惡 き A. は水化作用速にして，墓縮り上き $\mathrm{B}$ は水化作用遲い。之は水蒸氣の吸着の多少 に依る事与大にあると考へらる。此の事は

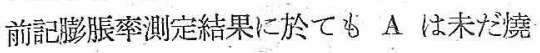
縮まらざる事を述べたが正にその通りで市 る，耐覧强度と消化との關係を見ると酎㗨 强度の强きもの程水㘳作用に强い事方゙判 る, 文 $\mathrm{A}$ に於ては $\mathrm{SiO}_{2}, \mathrm{CaO}$ 共に多い.

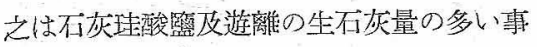
を意味する。

3）石川總雄，佐野芧吉，日化，53，703 $\sim 707,1932$.

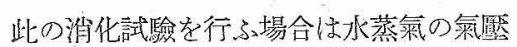
を2埭買としたる場合は 2 万至 3 時間まで 正型家保ら，6 万至 7 時間の間にて崩壊す る.

此の試驗を以て2 品筫決定の標準となし 且短時闑に試驗せん鹪には2 埭壁以上に上 ぐる必要がある。且又試片Aの如き成型撘 低く憢縮り小なるるのは1時間まで正型を 保ち，約 4 時間にて既に崩境して居る故に 4〜5 時間に於ける結果を見る必要があり， 正型を保つ時間が $2 〜 3$ 洔間で，崩燷する 迄の時間が 6 時間以上のものは使用に際し 今日の狀態では標淮品と見做す事を得べき ものである。

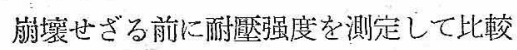
する場合は水蒸氣壓. 1 1.5 氣壓に於て长 否を制定する事が出來る，郎良品は1氣擫 の場合 8 時間作用せしめて耐壓强度が牛娍

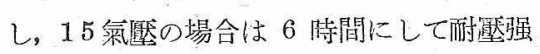
度牛減する事になるが，Aの如き不良品は 1 氮厤 4 洔間にて既に $42 \%$ となる。1.5 㴋 壓にては 3 時間にて約 $42 \%$ となる。中間 品 $\mathrm{C}$ は1氣嶎 6 時間にて $42 \%, 1.5$ 氣㕍 3 時間にて約 $49 \%$ なる. か子る狀態なる を以て低氣厴短時間に於て試驗を望む場合

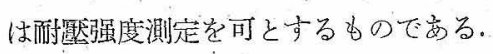

前述の如く他の性質より考察した練瓦の 良否と，現在の法の良否の結果とは一致 して居る故此の方法を標準として使用愐瓦 の舆否を決定する事が㑁來ると考へる.

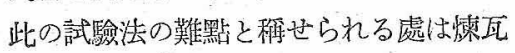
試料の不均一なる事にありと䊈せられ る。分膰整鐵所第二案業課, 黑崎窵業試驗 窒に於けるものは滿足すべき結果を得られ炇事を筆者に報ぜられて ॐる.

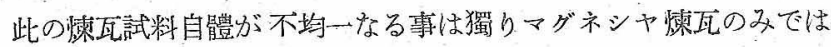

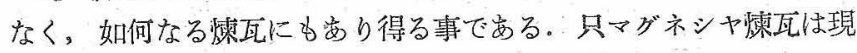
在の我邦の原料が舊㙞國品等に比較して憢結に高溫を要する故に， 先づ充分によく混合せらる事を必要とし，第二に充分なる强䑁を以 て成型なられ，第三に充分なる高溫憢成を行はなければならない事 は明である。办不注意に成型せらる」時には同一溫度でも燒縮り惡
マグネシャ煤瓦A 洞化試驗紹果室眞

(水蒸氯 1 氧 笽)

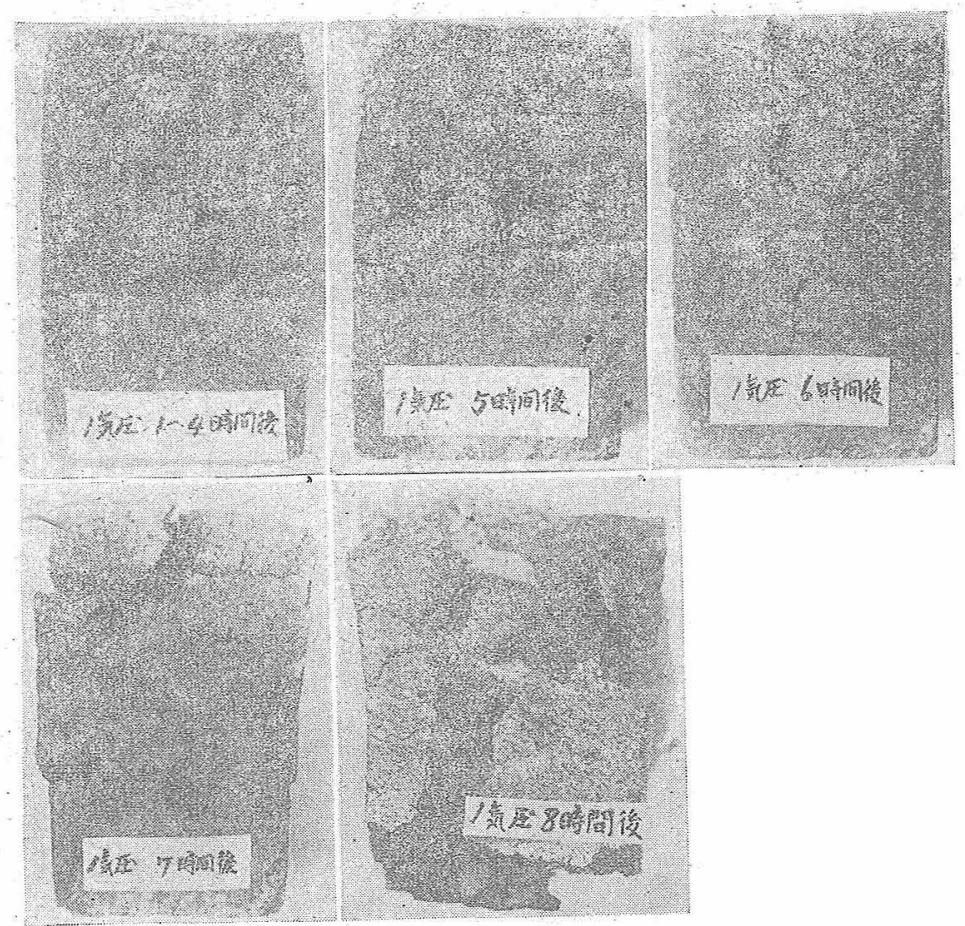

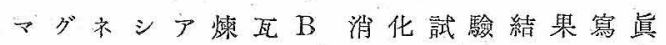

(水蒸策 1 氣檿)

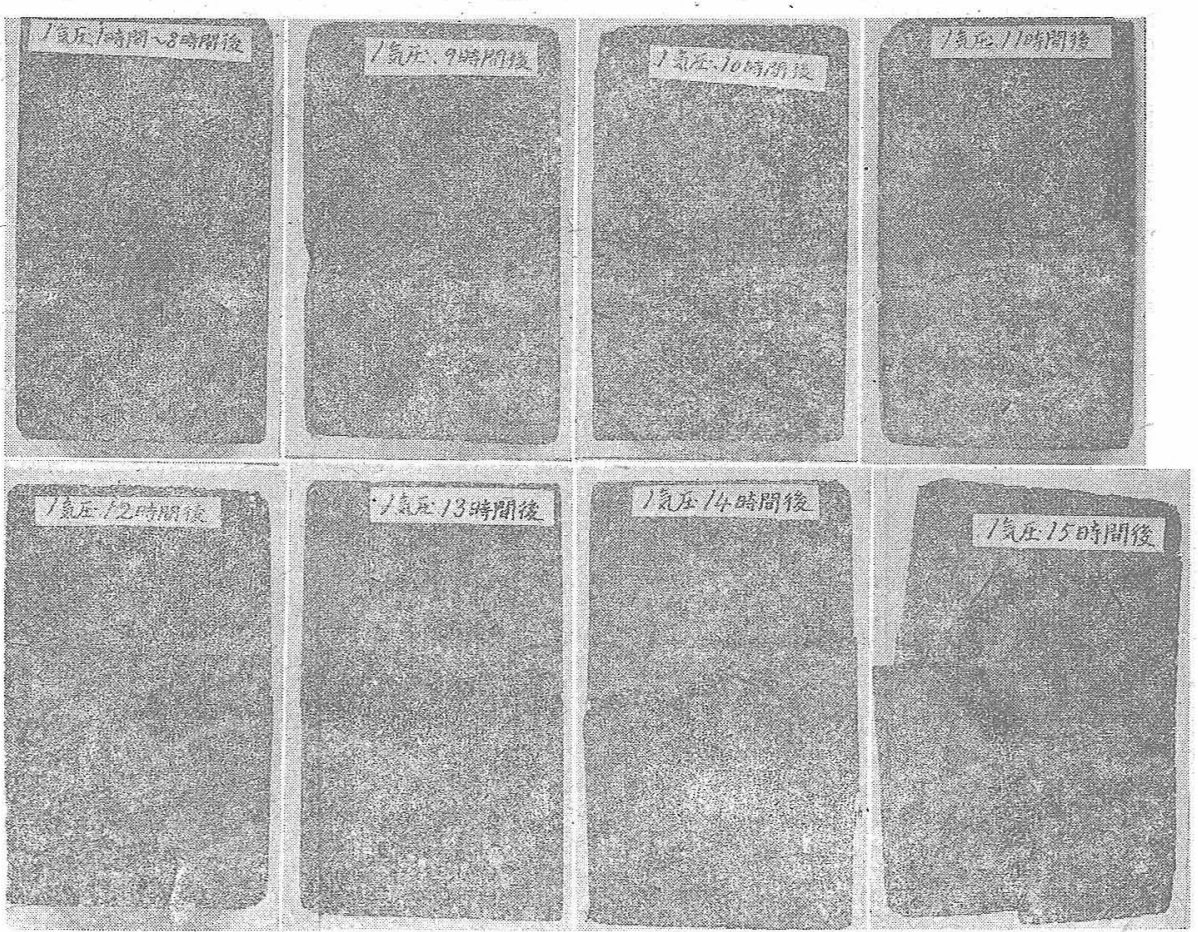

しき事は，此の試驗の試維に於てる既に明である。

吾ふはからる見地から試料の不揃で㚣る事は製造者に猛省る促し

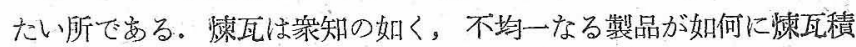
全體としての壽命に關係するかを痛切に感ぜられるものであるから

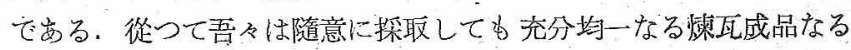
べき事を考慮に大れなければならない。然る時は消化試驗に對する 數量的判定は充分此の方法で行き得らるべきるのと思はれるのであ る。 
か」る時に此の試驗の施行方法として考 へらるさ事は一定数より1個といふ定割合。

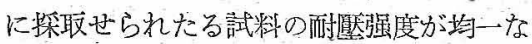
る事を條件とし，而してからる條件は霓瓦 使用の常識として一應蒱足せられたるもの と考へる箒とする。

然る時は此の試驗に於ける如きは比較的 首肯し得べき結果を得るので岕る。

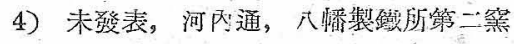
菜課報告

5）未發表，江崎光彔，黑崎栔業試驗室

$$
\text { V. 結 : 言 }
$$

1. 本試驗に於ては從來の肉服觀察に止

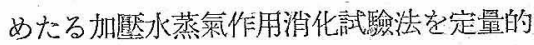
に考察する目的を以て耐厴强度測定法を併 用したる消化試驗を行つた

2. 憘縮りの惡いるのは急涑に消化作用 を受ける。

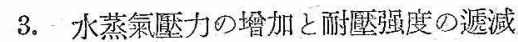
とは扰物線的閣係にある。

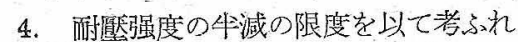
ば 1。氣厎 4〜5 特間で試驗を終る事が出 來る。

5. 耐壓强度の減少率を以て成品の良否を判定与る事が出來る。

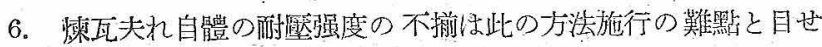
られる。之は製造法の幻稚なる事にある故に大に改良する必要が繁 るが製造者の技術の進步と誠意とに俟て充分滿足せらるべきるの 考へられる故に此の試驗法は充分數理的標準として考慮する資料と

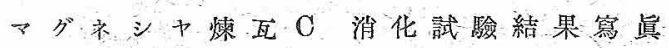

(水蒸 氣 1 氯 厴)

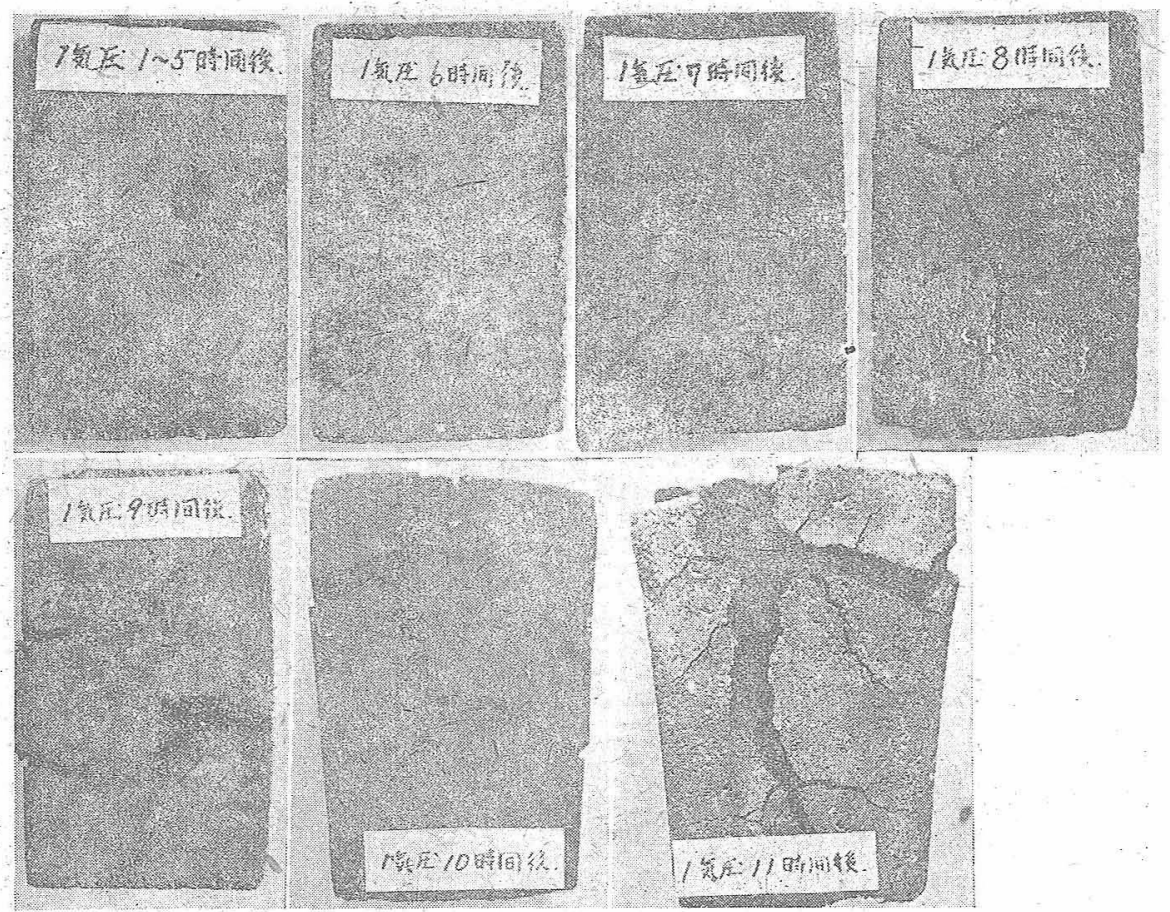

なり得ベきものである。

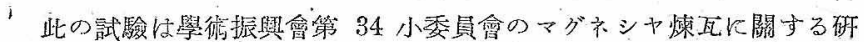
究の一部をなすものである、昭和 15 年 8 月〜 16 年 4 .月昭和製鈛

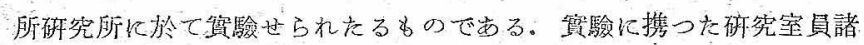

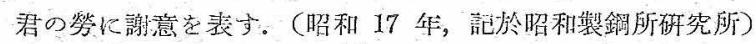

